\title{
TEACHING PROOF TO STUDENTS USING EXPERIMENTAL MATHEMATICS
}

\author{
Toshpolatov M.T.
}

Teacher Of Math Department, Andijan State University, Uzbekistan

Abdullayev A.X.

Teacher Of Math Department, Andijan State University, Uzbekistan

Zaynobiddinov I.S.

Teacher Of Math Department, Andijan State University, Uzbekistan

\section{ABSTRACT}

This article focuses on teaching students how to use experimental mathematics in proving mathematical proofs. Firstly, the proofs of the theorem are analyzed by experiment and as a result of the ability of intuitive thinking, it is proved analytically. In the process of training, using experiments will increase the quality of the educational system.

KEYWORDS:- Experimental mathematics, proof, experiment, logic, intuition, notion, consciousness, triangle, bisector.

\section{INTRODUCTION}

Experimental mathematics is the field of mathematics that generates a result in the support of experiments, the use of modern computing machines for the verification of equations. The increase in the possibilities of modern computing machines took an important place in the development of experimental mathematics. All the results obtained in experimental mathematics are confirmations that have a solid proof.

It is very important to follow the proof every step. If we understand the proof as a holistic one, then each of its elements must perform its function correctly in its place. This results in confusion in proving that the optional element of tokens does not perform its function properly. It is very important to follow the proof every step. Otherwise, his attachment will disappear, and he can get confused at any time. It is important to understand the proof in the construction,each part of it must be in its place. Proof that has not been taken as a whole does not prove anything. Even if you memorize it, no knowledge is added to the knowledge that precedes it from the beginning to the end.

Less time is allocated to prove mathematical laws in higher educational institutions due to the fact that lecture classes are decreasing. The use of mathematical experiments to close this gap gives a very good result. Experiments take the student's interest in the subject to a new level. It 
CURRENT RESEARCH JOURNAL OF PEDAGOGICS 2(9): 52-56, September

2021 DOI: https://doi.org/10.37547/pedagogics-crjp-02-09-12

ISSN 2767-3278

(C)2021 Master Journals

\section{Crossref dof 81 Google}

Accepted 24th September, 2021 \& Published 29thSeptember, 2021

is widely available in computer software packages when conducting experiments. Seeing the expected result through the program gives a great impetus in advancing the initial hypothesis. In this it is necessary to emphasize the role of intuition.

"Intuition" is as the latin word, which means "to look closely", and it is the ability to understand the truth, which is not based on it with the help of solid, logical proof. Thus, intuition is a specific concept that contradicts logic and perseverance. There are two types of intuition: intuitive reasoning and intuitive hypothesis. In the intuitive reasoning, which is the first type of intuition, the obyektiv attachment of things and the direct view of reality are carried out without any solid logical proofs. The peculiarity of intuitive reasoning is that the truth realized through it is not logically proved, and the presence of such a proof is also impossible. Intuitive reasoning, thinking consists of an action that has at once, at some point, a generalizing feature. Intuition is the direct, abnormally real perception of the properties of the cognition object, which can not be based on it in a different way under certain conditions. In other words, intuition is often considered to be the solution of the problem in zum because of the lack of logical grounds. General appearance mathematical intuition develops gradually, depending on the mathematical experience. Therefore, the more experience the mathematician has, the more he can trust his intuition. Intuition can be viewed as the main driving force of mathematical creativity. Intuition is a great motivation for us to draw conclusions about some understanding. We can not algorithm it. Therefore, at first it will be hidden under the full consciousness, and we can only understand it from the results by interpreting it. [2]

Intuition and creativity are two interesting manifestations of the phenomenon of consciousness in a person's life. Consciousness is a feature that expresses the essence of man, expresses the subjective reality, the perception of the external environment in man, his consciousness and his permission, the spiritual world of man, his conscious understanding of his existence in the universe, his active, creative attitude to the external environment. [3]

Feeling and rational knowledge of the laws of the subject's existence, its properties and relations can be a vivid example of the creative activity of consciousness. But the creative process of a person, which takes place on a conscious level, penetrates even deeper into the subconscious and subconscious layers of his psyche. According to the scientific imagination of the present time, the sphere of mental activity of a person under the subconscious mind sometimes includes sensations, imaginations that the mind does not understand. The subconscious sphere of consciousness embraces anxious sensations on the eve of a dream of a spiritual life, a state of hypnosis, incomprehensible desires, anxious sensations, for example, an unpleasant event in a person's life.

Intuition is the inner, the side of this creative activity, in which the unconscious component is directed towards the generalization, unification, understanding of the results of cognitive activity. At the same time, it is necessary not to over simplify the interaction of consciousness and unconsciousness, intuition in scientific creativity, already this is a very complex, confusing and rather mavhum process. For Example, D.I. Mendeleyev almost solved the task of creating the system of elements davriy, but the mind did not allow this solution to pass from the subconscious to the sphere of consciousness, while the mind "slept" in the literal sense of the word, the finished result from under the consciousness "sailed" and the scientist woke up and noted it on paper. 
CURRENT RESEARCH JOURNAL OF PEDAGOGICS 2(9): 52-56, September

2021 DOI: https://doi.org/10.37547/pedagogics-crjp-02-09-12

ISSN 2767-3278

(C)2021 Master Journals

\section{Crossref doi) 81 Google}

Accepted 24th September, 2021 \& Published 29th September, 2021

Many actions that occur unconsciously, instinctively, a person performs the function of protective forces and protects the brain from falling into a certain weight. It is controlled and controlled by the subconscious. The views, habits, tendencies of the individual are also associated with an unconscious sockeye, while intuition is the product of the unconscious on the basis of previously obtained and stored information about the functions of the laid.

If the mathematical thought coming out of every mathematician is understandable to every member of it when the concept is presented to the team of mathematicians and its supportlasa it is called collective intuition. But the opinion of a member of the team that out of the general understanding of collective intuition can have special parts head int intuition is individualized, that is, it is isolated and the basis of the work that is being created in its special parts. Such an intuition is called an individual or individual intuition.

Mathematical knowledge of high students should consist of 2 main components-intuition and a storehouse of knowledge. Intuition relies on knowledge in its development. When directly explaining new concepts to schoolchildren, it is necessary to increase his knowledge, but not undermine his individual intuition. Also it developed an imaginary, hypothetical mathematical intuition that occurs along with the experiment, leading to a solution.

Theorem. Triangular bisectors intersect at one point.

\section{PROGRAMM}

procedure

TForm1.Button3Click(Sender: TObject);

var j,v:integer;

a,i,k:real;

begin with Form1.Canvas do

begin

$\mathrm{v}:=1$;

$\mathrm{a}:=0.01$;

$\mathrm{k}:=350$;

$\mathrm{i}:=80$;

while $\mathrm{i}<=300$ do

for $\mathrm{j}:=1$ to $\mathrm{v}$ do

begin

pixels[trunc(i),trunc(k)]:=9;

$\mathrm{k}:=\operatorname{round}((\mathrm{i}-80) / 220 *(-330)+350)$;

$\mathrm{i}:=\mathrm{i}+\mathrm{a}$;

end;

$\mathrm{i}:=80$;

while $\mathrm{i}<=600$ do

begin

for $\mathrm{j}:=1$ to $\mathrm{v}$ do

pixels[trunc(i),350]:=9;

$\mathrm{i}:=\mathrm{i}+\mathrm{a}$;

end;

$\mathrm{k}:=350$;

$\mathrm{i}:=600$;

while $\mathrm{i}>=300$ do

begin

for $\mathrm{j}:=1$ to $\mathrm{v}$ do

pixels[trunc(i),trunc(k)]:=9;

$\mathrm{k}:=\operatorname{round}(((\mathrm{i}-600) /(300)) *(330)+350)$;

$\mathrm{i}:=\mathrm{i}-\mathrm{a}$;

end;

$\mathrm{k}:=350$;

$\mathrm{i}:=600$; 
CURRENT RESEARCH JOURNAL OF PEDAGOGICS 2(9): 52-56, September

2021 DOI: https://doi.org/10.37547/pedagogics-crjp-02-09-12

ISSN 2767-3278

(C)2021 Master Journals

Crossref dof 81 Google

Accepted 24th September, 2021 \& Published 29th September, 2021

while i $>=190$ do

begin

for $\mathrm{j}:=1$ to $\mathrm{v}$ do

pixels[trunc(i),trunc(k)]:=9;

$\mathrm{k}:=\operatorname{round}(((\mathrm{i}-600) /(410)) *(165)+350)$;

$\mathrm{i}:=\mathrm{i}-\mathrm{a}$;

end;

$\mathrm{k}:=185$;

$\mathrm{i}:=450$;

while $\mathrm{i}>=80$ do

begin

for $\mathrm{j}:=1$ to $\mathrm{v}$ do

pixels[trunc(i),trunc(k)]:=9;

$\mathrm{k}:=\operatorname{round}(((\mathrm{i}-80) /(370)) *(-165)+350)$; $\mathrm{i}:=\mathrm{i}-\mathrm{a}$;

end;

$\mathrm{k}:=350$;

$\mathrm{i}:=340$;

while $\mathrm{i}>=300$ do

begin

for $\mathrm{j}:=1$ to $\mathrm{v}$ do

pixels[trunc(i),trunc(k)]:=9;

$\mathrm{k}:=\operatorname{round}(((\mathrm{i}-340) /(40)) *(330)+350)$;

$\mathrm{i}:=\mathrm{i}-\mathrm{a}$;

end;

end;

end;

As a result of the program, the following graph is formed. As can be seen from the result, the Triangle bisectors intersect at one point, and this will be a great motivation for analytical proof.

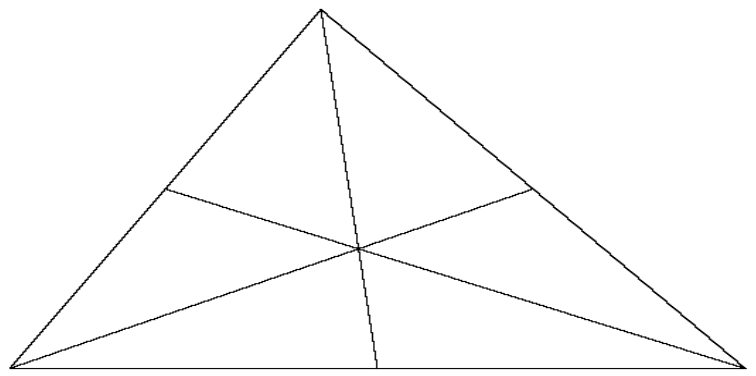

Figure 1

Proof. To prove the theorem, we draw 2 bisectors of the Triangle. Understandably, they intersect at one point and do not have another intersection point. The picture below depicts the intersection of the bisectors of angles $A$ and $B$ at point $O$. From point $O$ we pass perpendicular to the sides of the triangle:

$\mathrm{OP} \perp \mathrm{AB}, \mathrm{OQ} \perp \mathrm{BC}, \mathrm{OR} \perp \mathrm{CA}$. 


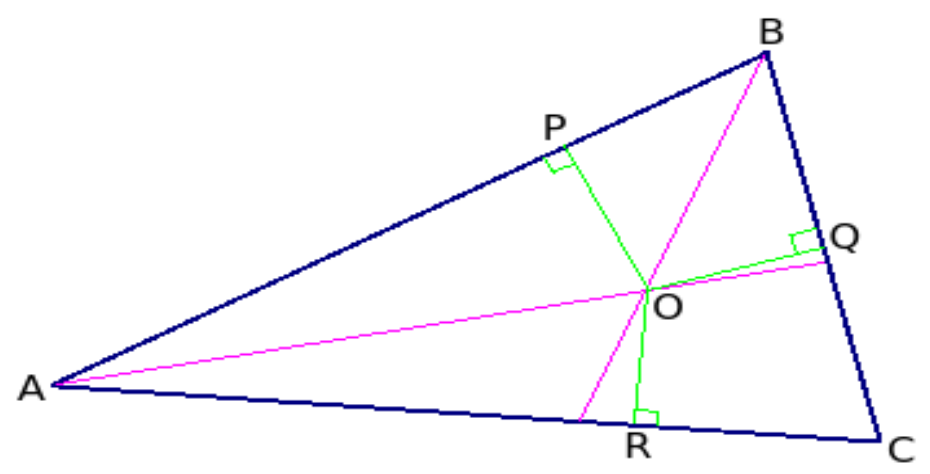

Figure 2

As you know, the perpendicular intersections are perpendicular intersections, which are transferred from the optional point of the angle bisector to the sides of the same angle, and they are mutually equal. This is due to the equality of rectangular triangles. For example: $\Delta \mathrm{AOP}=\Delta \mathrm{AOR}$ triangles in figure 2 are equal, they have a common hypotenuse and an equal angle at the end of $\mathrm{A}$.

So OP=OR because they are perpendicular to the sides from the optional point of the bisector coming out of the A end. Also $\mathrm{OP}=\mathrm{OQ}$ because they are perpendicular dropped from the sides from the optional point of the bisector removed from the $\mathrm{B}$ end. $\mathrm{OP}=\mathrm{OR}$ and $\mathrm{OP}=\mathrm{OR}$ are turn out from $\mathrm{OR}=\mathrm{OQ}$. So the point $\mathrm{O}$ is located at the same distance from the $\mathrm{BC}$ and $\mathrm{CA}$ sides of the triangle. These sides are those that form the angle C. As you know, if the point in the corner lies at the same distances from the sides, then it lies in the corner bisector. Further $\mathrm{O}$ Point $\mathrm{C}$ lies in the corner bisector. In this way, the $\mathrm{C}$ angle bisector passes through the point where the other 2 angle bisectors intersect. This means that the bisectors of the triangle intersect at one point. The proof is over.

It is also possible to see the intersection of the medians, heights of triangles at one point in this way.

\section{REFERENCES}

1. Пуанкаре А. О науке. - М.: Физматлит, 1983.

2. Falsafa asoslari. ( Tuzuvchi va mas'ul muharrir: Q. Nazarov). - Toshkent: «O'zbekiston» nashriyot-matbaa ijodiy uyi, 2005.

3. Математическое мышление (Герман Вейль-перевод с английского и немецкого Ю.Данилова). - Москва: «Наука» главная редакция физико-математической литературы, 1989.

4. Громаковская Л.А. Экспериментальная математика как одно из средств развития потребности в логическом доказательстве, Труды ПгУ. Математика, 2002, выпуск 9, 54-61 